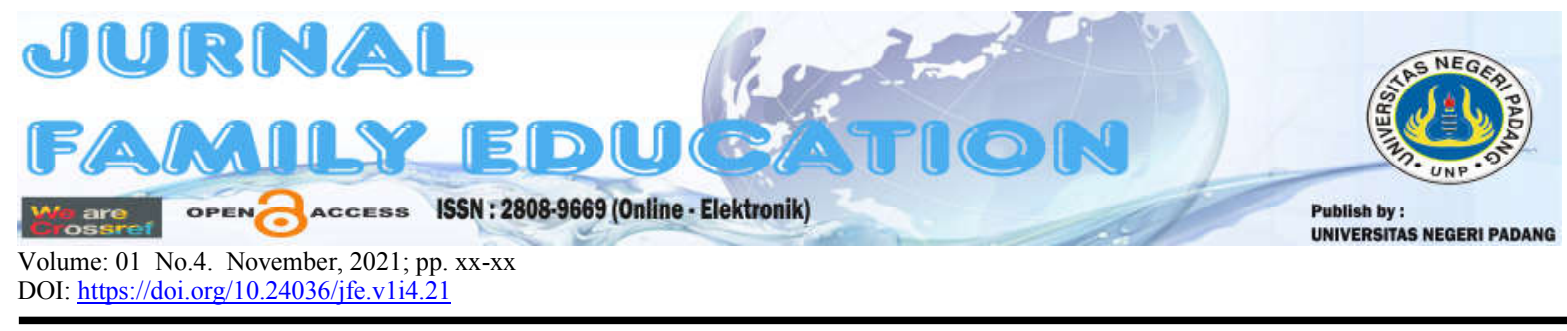

\title{
Strategi Perkembangan dan Indikator Pencapaian Bahasa Reseptif dan Bahasa Ekspresif pada Anak Usia Dini
}

\author{
${ }^{1}$ Amalia Husna, ${ }^{2}$ Delfi Eliza \\ ${ }^{1}$ Magister Pendidikan Anak Usia Dini, Universitas Negeri Padang, \\ ${ }^{2}$ Magister Pendidikan Anak Usia Dini, Universitas Negeri Padang \\ * e-mail: ${ }^{1}$ amaliahusna622000@gmail.com, ${ }^{2}$ deliza.zarni@gmail.com
}

\begin{abstract}
This study aims to determine language development strategies and indicators of achievement of receptive and expressive language in early childhood. This type of research is qualitative descriptive research, research using literature study research methods or literature study. Studying literature in this study, researchers used various written sources, namely, books, articles, journals and various documents that were relevant to the issues studied. There are several languages that must be developed in children, some of which are receptive language and expressive language. Receptive language is related to the ability to distinguish meaningful and meaningless sounds, receptive language is the ability to listen and read. Children's expressive language is the ability to express language verbally and non-verbally. From the research results, there are several strategies to help the development of receptive language, namely: (1) Storytelling activities; (2) Flashcards; (3) Language games (rehearse words, listen-do, listen-guess, whisper chain and tell stories). And some strategies to help children's expressive language development are: (1) Finger Puppet Play; (2) Role Playing
\end{abstract}

Keywords: Receptive Language, Expressive Language, Early Childhood

\section{PENDAHULUAN}

Pendidikan anak usia dini (PAUD) merupakan jenjang pendidikan anak sebelum menempuh pendidikan dasar sebagai upaya pembinaan untuk anak sejak lahir sampai usia 6 tahun, yang dilakukan dengan memberikan rangsangan pendidikan dengan tujuan membantu perkembangan pertumbuhan jasmani maupun rohani agar anak mempunyai kesiapan untuk memasuki pendidikan lebih lanjut yang dapat dilaksanakan pada jalur formal, nonformal dan informal (Madyawati, 2016: 2).

Masa Kanak-Kanak Awal Adalah Masa Perkembangan Anak Yang Terjadi Pada Usia Akhir Masa Bayi Sekitar 2 Tahun Sampai Usia 6 Tahun. Periode Ini Biasanya Disebut Juga Dengan Masa Prasekolah Anak. Pada Periode Ini Anak Belajar Untuk Mandiri, Mengembangkan Keterampilan, Kesiapan Dalam Menempuh Sekolah, Dan Bermain Dengan Teman Sebaya. Masa Ini Berakhir Dengan Ditandai Anak Memasuki Masa Kelas 1 SD (Santrock, 2007: 190).

Anak Usia Dini (AUD) Merupakan Pribadi Yang Unik. Anak Memiliki Kemampuan Dan Bakat Yang Luar Biasa Yang Apabila Mendapat Stimuasi Yang Tepat Akan Menjadikan Anak Tersebut Sebagai Seseorang Yang Luar Biasa Pula. Perkembangan Anak Adalah Peting Dipelajari Agar Memahami Aspek-Aspek Perkembangannya Sehingga Dapat Menyiapkan Strategi Untuk Merangsang Perkembangan Anak Agar Perkembangan Anak Menjadi Optimal (Khaironi, 2018: 11). 
Aspek-aspek perkembangan anak usia dini menurut Peraturan Menteri Pendidikan dan kebudayaan Nomor 137 tahun 2014 tentang standar nasional pendidikan anak usia dini adalah : (1) nilai agama dan moral, (2) Fisik-motorik, (3) Kognitif, (4) Bahasa, (5) Sosial-emosional, (6) Seni.

Bahasa merupakan sarana komunikasi dengan cara diucapkan, ditulis atau dilambangkan guna menyampaikan gagasan atau kemauan seseorang agar dapat dimengerti oleh orang lain (Robingatin dan Ulfah, 2019: 31).

Bahasa adalah alat komunikasi yang telah diperoleh oleh setiap manusia sejak lahir ke dunia. Kemampuan berbahasa pada anak dimulai sejak ia memperolah bahasa pertama kalinya yang sering disebut dengan bahasa ibu (Suardi, dkk, 2019: 266).

Bahasa pada anak berkembang dari sederhana ke kompleks. Perkembnagan bahasa anak sejalan dan dipengaruhi oleh interaksi sosial, perkembangan emosi, kemampuan kognitif, dan perkembangan fisik/motorik (Palupi, 2018: 34).

Bahasa Berfungsi sebagai alat komunikasi seperti berbicara, mendengarkan, membaca, dan menulis, mengembangkan kemampuan intelektual pada anak, mengembangkan ekspresi anak, dan membantu anak dalam mengungkapkan gagasan, dan perasaannya kepada orang lain (Robingatin dan Ulfah, 2019: 31).

Dengan berbahasa anak bisa mengekspresikan diri dan melakukan komunikasi dengan temannya, Mulai dari anak melakukan interaksi satu sama lain, melakukan pembelajaran dan perkembangan anak (Eliza, 2021: 649).

Bahasa lisan merupakan salah satu bentuk komunikasi secara verbal. Komunikasi secara lisan bertujuan untuk menyampaikan dan menerima informasi. Proses penyampaian informasi secar lisan disebut berbicara, sedangkan proses penerimaan informasinya disebut mendengarkan (Natalia dan Gandana, 2019: 65).

Berbicara adalah mengucapkan kata-kata untuk mengekspresikan pikiran, gagasan dan perasaan secara lisan. Berbicara adalah bentuk perilaku manusia yang menggunakan faktor fisik, psikologis, neurologi, semantik, dan linguistik. Pertama, pada faktor fisik yaitu alat ucap untuk mengahsilkan bunyi bahasa, seperti kepala, tangan, dan roman muka yang dimamfaatkan dalam berbicara. Kedua, faktor psikologis dapat mempengaruhi kelancaran bahasa, seperti stabilitas emosi yang dapat mempengaruhi kuliatas suara dan susunan bahan pembicaraan. Ketiga, faktor neurologis yaitu jaringan saraf yang menghubungkan otak kecil dengan mulut, telinga dan organ tubuh lainnya yang terlibat dal proses berbicara. Keempat, faktor semantik yang berhubungan dengan makna atau arti dari apa yang ingin dibicarakan. Kelima, faktor linguistik yang berkaitan dengan struktur bahasa (Kurnia, 2019: 2).

Pertumbuhan bahasa mengilustrasikan bagaimana semua aspek perkembangan berinteraksi. Seiring dengan struktur fisik untuk menghasilkan suara menjadi sempurna, dan koneksi neural yang dibutuhkan untuk menghubungkan suara makan menjadi aktif, interaktif sosial dengan orang dewasa memperkenalkan anak kepada karakteristik komunikasi bahasa. Adapun komponenkompenen dalam bahasa antara lain (Jalongo, 2007: 67-72):

a. Pragmatik (sistem interaksi sosial)

Pragmatik berkaitan dengan siapa yang dapat berbicara, kepada siapa mereka dapat berbicara, apa yang dikatakan, bagaimana cara mengatakannya, kapan dan dimana mereka mengatakannya dan media apa yang digunakan. Misalkan mengucapkan kata "terima kasih" ketika menerima bantuan. Contoh lain, ketika menyampaikan kritik kepada atasan, maka hendaknya dismpaikan menggunakan bahasa yang sopan, bahasa formal, tidak disampaikan di depan banyak orang. Contoh lainnya, saat berkomunkasi dengan teman sebaya menggunakan bahasa informal, bahasa sehari yang santai dan mudah dipahami atau bahkan bisa menggunakan bahasa gaul. Sedangakan saat berkomukasi dengan guru menggunakan bahasa yang lebih formal dan sopan (Jalongo, 2007: 68).

b. Semantik (Sistem Makna) 
Amalia Husna, Delfi Eliza

Pada Anak-anak arti kata atau semnatik, anak-anak belum mengetahui kata-kata yang benar. Contoh komponen semantik atau sistem makna pada anak adalah pada saat anak mengaitkan kata "Da-da" yang berkaitan dengan keberangkatan (Jalongo, 2007: 67).

c. Sintaks (Sistem Tata Bahasa)

Sintaks ini berkaitan dengan sistem tata bahasa, contoh komponen sintaks pada perilaku anak adalah pada saat anak menyadari misalakan dalam bahasa inggris dimana kata-kata yang berkhiran s menunjukkan makna jamak (Jalongo, 2007: 67).

d. Grafofonik/Fonem (Sistem Bunyi)

Contoh perilaku anak pada kompenen grafofonik adalah pada saat anak sudah mulai memahami bagaimana nada bicara sesorang saat bertanya, misalkan pertanyaan "apakah kamu sakit?" anak bisa meresponnya dengan tepat dengan mengucapkan kata "ia" atau "tidak" (Jalongo, 2007: 67).

Adapun tahap-tahap perkembangan bahasa pada anak adalah sebagai berikut (Jalongo, 2007: 75):

a. Tahap Pralinguistik. Pada tahap ini anak Membuat suara seperti berbicara tapi tidak ada katakata. Berlangsung pada usia 0-1 tahun.

b. Tahap Linguistik. Pada tahap Anak sudah bisa membuat ucapan satu kata. Berlangsung pada anak-anak usia 1-2 tahun.

c. Membuat Kata Menjadi Frase. Fase ini berlangsung sewaktu anak berusia sekitar 2-3 tahun. Pada masa ini, kosa kata dan gramatika anak berkembang dengan cepat. Anak-anak mulai menggunakan dua kata dalam berbicara.

d. Menggunakan Bahasa Lengkap. Fase ini anak mengelami Pengucapan dan tata bahasa meningkat. Berlangsung ketika anak berusia 4-6 tahun atau bahkan sampai mulai bersekolah. Dapaun indikator tahapannya adalah:

e. Menggunakan Bahasa Secara Simbolis (Membaca, Menulis)

Ada beberapa bahasa yang harus dikembangakan pada anak beberapa diantaranya adalah bahasa reseptif dan bahasa ekspresif. Menurut Permendikbud Nomor 137 (2014: 5) bahasa reseptif, mencakup kemampuan memahami cerita, perintah, aturan, menyenangi dan menghargai bacaan. Namun belum ada penelitian yang menjelaskan secara rinci bagaiamana bahasa reseptif, bahasa ekspresif dan staregi serta indikator pencapaian dalam perkemabangan bahasa tersebut.

Menurut Permendikbud Nomor 137 (2014: 2) bahasa reseptif adalah berkaitan dengan kemampuan dalam membedakan suara yang bermakana dan tidak bermakna, bahasa reseptif adalah kemampuan dalam menyimak dan membaca.

Menurut Permendikbud Nomor 146 (2014: 8) bahasa ekspresif anak adalah kemampuan dalam mengungkapankan bahasa secara verbal dan non verbal. Berbicara termasuk pada kemampuan bahasa ekspresif. Bromley menyatakan kemampuan berbicara merupakan suatu ucapan dalam bentuk kata kata.

\section{METODE}

Penelitian ini bertujuan untuk mengetahui startegi perkembangan bahasa reseptif dan bahasa ekspresif pada anak usia dini. Metode penelitian yang diginakan dalam penelitian ini adalah metode studi literatur. Metode penelitian studi literatur sering juga disebut dengan studi pustaka. Metode ini dilakukan dengan mengumpulkan berbagai macam informasi dari berbagai sumber yang ada di perpustakaan atau buku maupun data yang ada di internet yang berkaitan dengan masalah yang ingin dipecahkan menggunakan teknik tertentu yang sisitematis (Sari, 2020: 53). Adapun langkah-langkah studi literatur atau studi pustaka menurut (Zed, 2004: 17-22) adalah: (1) tahap persiapan; (2) menyusun catatan yang digunakan mengenai sumber utama data; (3) mengatur waktu; (4) membaca dan membuat catatan penelitian. 


\section{HASIL DAN PEMBAHASAN}

\section{Pengertian Bahasa Reseptif Anak Usia Dini}

Menurut Permendikbud Nomor 137 (2014: 5) bahasa reseptif pada Anak, mencakup kemampuan memahami cerita, perintah, aturan, menyenangi dan menghargai bacaan. Menurut Permendikbud Nomor 137 (2014: 2) bahasa reseptif adalah berkaitan dengan kemampuan dalam membedakan suara yang bermakana dan tidak bermakna, bahasa reseptif adalah kemampuan dalam menyimak dan membaca.

Bahasa reseptif merupakan kemampuan untuk memahami kata dan bahasa melibatkan perolehan informasi serta makna dari aktifitas sehari-hari (misalnya setelah menyelesaikan sarapan, selanjutnya saatnya kita berpakaian, informasi visual dalam lingkungan (misalnya ibu memegang kuncinya berarti kita akan naik mobil, lampu hijau berarti pergi), suara dan kata-kata (misalnya sirene artinya mobil pemadam kebakaran akan datang, kata bola berarti benda bulat yang melenting bermain dengan), konsep seperti ukuran, bentuk, warna dan waktu, tata bahasa (misalnya jamak biasa: cat/s) dan informasi tertulis (misalkan tanda-tanda di lingkungan seperti "tidak memanjat", cerita tertulis) (Khosibah dan Damyati, 2021: 1862).

Perkembangan bahasa reseptif merupakan bagian dari proses perkembangan dan pembelajaran yang terkoordinasi dengan baik yang dipengaruhi oleh faktor biologis dan sosial budaya, mulai dari kelahiran dan interaksi awal (Yildiz, et al, 2019: 2). Bahasa reseptif mengacu pada anak yang menerima bahasa dan berperilaku sesuai. Jika diurutkan dalam pemerolehan, keterampilan berbahasa dapat didaftar sebagai berikut; mendengarkan, berbicara, membaca dan menulis. Mendengarkan dan membaca dianggap keterampilan bahasa reseptif. Mendengar dan membaca dianggap atau teermasuk bahasa reseptif (Altınkaynak, 2019: 894).

\section{Indikator Bahasa Reseptif Anak}

Adapun Indikator bahasa Reseptif anak menurut Permendikbud Nomor 146 (2014: 30-31) adalah:

a. Lahir Sampai Kurang dari 3 Bulan. Merespon semua suara yang diperdengarkan, dan tampak tenang ketika diperdengarkan musik.

b. 3 Bulan Sampai Kurang dari 6 Bulan. Merespon suara yang dikenal dengar cara menatap wajah orang yang mengajak bicara.

c. 6 Bulan Sampai Kurang dari 9 Bulan. Menunjukkan reaksi mealalui ekspresi wajah dan gerak tubuh ketika diajak berbicara, mislakan menggerakkan tangan dan kaki ketika mendengara suara orang yang akarab didengar.

d. 9 Bulan Sampai Kurang dari 12 Bulan. Menggerakkan mata kearah objek yang diperlihatkan.

e. 12 Bulan Sampai Kurang dari 18 Bulan. Menggarukkan atau menggelengkan kepala ketika diberikan pertanyaan.

f. 18 Bulan Sampai Kurang dari 2 Tahun. Menjawab pertanyaan dengan kalimat sederhana; Melaksanakan satu perintah sederhana.

g. 2 Tahun Sampai Kurang dari 3 Tahun. Menjawab pertanyaan sederhana; Melaksanakan dua perintah sederhana.

h. 3 Tahun Sampai Kurang dari 4 Tahun. Memebedakan perintah, pertanyaan dan ajakan; Melaksanakan 3 atau lebih perintah sederahana.

i. 4 Tahun Sampai Kurang dari 5 tahun. Menceritakan kembali apaa yang didengar dengan kosa kata yang terbatas; Melakasanakan perintah sederhana sesuai dengan aturan yang disampaikan (misalkan: aturan makan bersama).

j. 5 Tahun Sampai Kurang dari 6 tahun. Menceritakan kembali apa yang didengar denga kota kata yang lebih; Melaksanakan perintah yang lebih kompleks sesuai dengan perintah yang disampaikan (misalnya: aturan dalam melakukan kegiatan memasak ikan).

\section{Pengertian Bahasa Ekspresif}


Menurut Permendikbud Nomor 137 (2014: 5) mengekspresikan bahasa, mencakup kemampuan bertanya, menjawab pertanyaan, berkomunikasi secara lisan, menceritakan kembali yang diketahui, belajar bahasa pragmatik, mengekspresikan perasaan, ide, dan keinginan dalam bentuk coretan.

Menurut Permendikbud Nomor 146 (2014: 8) bahasa ekspresif anak adalah kemampuan dalam mengungkapankan bahasa secara verbal dan non verbal. Berbicara termasuk pada kemampuan bahasa ekspresif. Bromley menyatakan kemampuan berbicara merupakan suatu ucapan dalam bentuk kata kata. Kemampuan bahasa ekspresif anak diusia 4-5 tahun menurut Steinbrg dan Gleason termasuk dalam perkembangan kombinatori dimana anak sudah mampu berbicara secara teratur dan terstruktur, pembicaraan dapa dipahami oleh seseorang lain yang anak sanggup merespon baik positif maupun negative atas pembicaraan lawan bicaranya.

Bahasa ekspresif penting untuk perkembangan anak yang sehat, karena merupakan faktor pelindung terhadap perilaku agresif dan memainkan peran penentu dalam IQ verbal dan kinerja di kemudian hari, keberhasilan akademik dan literasi (Laranjo \& Bernier, 2013: 959).

Bahasa ekspresif di sisi lain mengacu pada kemampuan anak untuk mengekspresikan dirinya berdasarkan pengamatannya, emosi atau perasaan. Jika diurutkan dalam pemerolehan, keterampilan berbahasa dapat didaftar sebagai berikut; mendengarkan, berbicara, membaca dan menulis. Mendengarkan dan membaca dianggap keterampilan bahasa reseptif dan berbicara dan menulis dianggap keterampilan bahasa ekspresif (Altınkaynak, 2019: 894).

\section{Indikator Bahasa Ekspresif Anak}

Adapun indikator bahasa ekspresif anak Menurut Permendikbud Nomor 146 (2014: 31-33) adalah:

a. Lahir Sampai Kurang dari 3 Bulan. Merespon intonasi suara; Bereaksi terhadap kejadian yang ada di sekitarnya sesuai dengan stimulus yang ada/terjadi.

b. 3 Bulan Sampai Kurang dari 6 Bulan. Menunjukkan ketertarikan pada suara-suara yang didengar; Menunjukkan ketertarikan pada gambar berwarna; Mengeluarkan berbagai macam bunyi/suara bayi sesuai dengan stimulus yang dilakukan.

c. 6 Bulan Sampai Kurang dari 9 Bulan; Menirukan bunyi yang didengar yang terdiri dari satu suku kata secara berulang; Meraih buku atau gambar yang diperlihatkan; Mengeluarkan berbagai macam bunyi (tertawa saat senang, sesuai dengan stimulus yang dilakukan).

d. 9 Bulan Sampai Kurang dari 12 Bulan. Menirukan bunyi yang didengar yang terdiri dari dua suku kata; Memegang buku gambar; Menjawab pertnyaan dengan gerak tubuh (mengangguk dan menggeleng); Mengungkapakan kata pertema (mama, papa, dada) dan lainnya sesuai contoh yangs sering didengar.

e. 12 Bulan Sampai Kurang dari 18 Bulan. Menirukan kata-kata pendek dan mudah yang diajarkan; Mulai menunjukkan ketertarikan ketika dibaca buku cerita; Merespons pertanyaan sederahana yang diajukan dengan suku kata terbatas; Mengungkapakan kata sederhan (mislakan: mam, yang berarti saya ingin makan).

f. 18 Bulan Sampai Kurang dari 2 Tahun. Menggunakan kata-kata pendek dan mudah untuk mengungkapkan keinginanya; Menyukai dibacakan buku yang sama berulang-ulang; Berbicara dengan dua kata atau lebig tentang benda atau tindakan tertentu; Mengungkapkan kata sedrhana dengan lebih jelas (mislakan: susu, yang artinya ingin minum susu).

g. 2 Tahun Sampai Kurang dari 3 Tahun. Menggunakan kalimat pendek dengan kosa kata terbatas untuk menyatakan apa yang dilihat dan dirasa; Membuka halaman buku; Berbicara dengan dua kata atau lebih tentang benda atau tindakan tertentu dengan nada yang sesuai dengan tujuan (misalkan: nada tanya, nada meberitahu); Mengungkapkan kalimat sederhana (misalkan: adik minum susu).

h. 3 Tahun Sampai Kurang dari 4 Tahun. Mengungkapkan kalimat pendek dengan kosa kata yang lebih banyak untuk mengungkapakan apa yang dilihat dan dirasa; Menunjukkan perilaku sperti sedang membaca buku; Berbicara dengan kalimat yang sederhana dengan nada yang 
sesuai dengan tujuan (misalkan: bertnya dan memebrikan pendapat); Mengucapkan kalimat sesuai dengan tujuan (kalimat tanya, pernyataan).

i. 4 Tahun Sampai Kurang dari 5 tahun. Menggunakan kalimat pendek untuk berinteraksi dengan anak atau orang dewasa untuk menyatakan apa yang dilihat dan dirasa; Menceritakan gambar yang ada didalam buku; Berbicara sesuai dengan kebutuhan (kapan harus bertanya, berpendapat); Bertanya dengan menggunakan lebih dari dua kata tanya (seperti: apa, mengapa, dimana).

j. 5 Tahun Sampai Kurang dari 6 tahun. Mengungkapkan keinginana, perasaan dan pendapat dengan kalimat sederhana dalam berkomunikasi dengan anak atau orang dewasa; Menunjukkan perilaku senang membaca buku dari buku-buku yang dikenali; Mengungkapan ide, perasaan dengan menggunakan pilihan kata yang sesuai saat berkomunikasi; Meceritakan kembali isi cerita dengan sederhana.

\section{Strategi Meningkatkan Kemampuan Bahasa Reseptif Anak}

1. Kegiatan bercerita

Menurut hasil penelitian Yuhasriati dan Fitriani (2017) dengan kegiatan bercerita dapat mengembangkan kemampuan bahasa reseptif pada anak. Metode bercerita adalah metode pembeljaran yang dilakukan dengan menarasikan suatu isi cerita kepada penyimak atau pendengar isi cerita tersebut. Dengan metode bercerita dapat meningkatkan ekmampuan berabahasa pada anak, khususnya pada anak usia 3-4 tahun. Penelitian dilakukan yang dialakukan oleh Yuhasriati dan Fitriani (2017) merupakan penelitian tindakan kelas yang dialaksanakan selama 2 siklus dan kesimpulan penelitiannyanya adalah metode bercerita dapat dilakukan dengan memberikan pertanyaan kepada anak, melibatkan anak secara langsung, dan mengaitkan cerita dengan kehidupan nyata anak. Hasil menunjukkan bahwa anak mampu menyebutkan tokoh, karakter tokoh dari cerita, dan anak sudah mampu menceritakan kembali isi cerita yang disampaikan artinya kemampuan bahasa reseptif anak usia 3-4 tahun berkembang dengan baik.

2. Flash Card

Flash Card merupakan kartu kata yang digunakan oleh guru. Flash card berupa potongan kertas atau kardus yang terdiri dari gambar, kata, atau kalimat sederhana agar guru dapat memperkenalkan berbagai kosa kata kepada anak. (Shehadeh \& Farrah, 2016).

Menurut hasil penelitian yang dilakukan oleh Alam dan Lestari (2020) Berdasarkan hasil penelitian dengan flash card yang digunakan ketika pembelajaran berlangsung memiliki peranan penting dalam mengembangkan bahasa reseptif anak usia dini. Pada kegiatan pembelajaran dengan menggunakan Flash card anak dapat menyimak serta mendengarkan guru memperkenalkan kata yang ada pada kartu, anak mengulang kata yang disebutkan guru, dan mengenal apa maksud dari kata tersebut melalui kata pada gambar. Dapat disimpulkan bahwa penggunakan Flash card dapat mengembangkan kemampuan bahasa reseptif pada anak.

3. Permainan bahasa (simak-ulang ucap, simak-kerjakan, simak-terka, bisik berantai dan bercerita)

Permaiana bahasa dengan metode ini adalah metode permainan yang dilakukan dengan menyenangkan untuk mengembangkan kemmapuan bahasa reseptif pada anak. Menurut hasil penelitian yang dilakukan oleh Tika (2021) menunjukkan bahwa dengan menggunakan per Permainan bahasa ini dapat mengembangkan kemampuan bahsa pada anak, terkhusus bahasa reseptif pada anak.

\section{Strategi Meningkatkan Kemampuan Bahasa Ekspresif pada Anak}

1. Sandiwara Boneka Jari

Berdasarkan hasil penelitian yang dilakukan Hariyanti (2019) disimpulkan bahwa melalui metode bercerita dengan menggunakan boneka jari terbukti efektif dapat meningkatkan kemampuan bahasa ekspresif anak. Peningakatan bahasa ekspresifa anak dengan metode bercerita mengguanakan boneka jari terlihat dari anak mampu menyampaikan atau berbicara dengan kalimat sederhana dan jelas untuk bertanya, menjawab pertanyaan guru, meceritakan kembali cerita yang didengarmya. 
Amalia Husna, Delfi Eliza

2. Bermain Peran

Menurut penelitian yang dilkukan dengan Yunita dan Rohmadheny (2020) dengan menggunakan metode bermain peran mampu meningkatkan bahasa ekspresif pada anak. Menurut Lickona (2016) bermain peran adalah kegiatan yang menyenangkan untuk dilakukan bagi siswa di semua umur, dimana siswa diajak untuk memainkan peran tertentu dalam suatu situasi moral."

"Dengan mengajak anak bermain peran, ia akan dapat belajar dalam berinteraksi bersama orang lain yang juga membawakan peran lain sesuai dengan tema dan kondisi yang dipilih. Selama pembelajaran bermain peran berlangsung siswa juga dapat melatih sikap empati, simpati, rasa benci, marah, senang serta peran lainnya (Viranda, 2019: 5)."

3. Partners' Dialogic Reading Program

Program Membaca Dialogik PARTNERS dapat memberika anak-anak kesempatan dalam berbagi pengalaman membaca bersama orang tua atau pengasuh mereka. Bentuk keterlibatan aktif ini penting karena meningkatkan perkembangan kosa kata anak-anak (Bloom, 2002) dan dapat memberikan anak-anak paparan kata-kata baru dengan cara yang bermakna di lingkungan mereka (Hart \& Risley, 1995). Menurut Brewer membaca adalah mendapatkan makna dari apa yang dibaca bukan Cuma mengungkapkan kata-kata (Brewer, 2007: 305).

Menurut hasil penelitian yang dilakukan oleh Brannon, et al (2013) Program PARTNERS dapat meningkatkan kemampuan bahasa ekspresif pada anak-anak yang tergolong "berisiko". Hal ini juga terbukti menjadi program yang efektif dalam mendorong keterlibatan dan pendidikan keluarga. Karena Program PARTNERS berfokus pada keluarga yang berbicara tentang buku dengan anak-anak mereka dari pada hanya membaca dengan suara keras, Program PARTNERS menyediakan materi yang dapat digunakan bersama keluarga terlepas dari tingkat literasi, bahasa rumah, atau bahasa ekspresif anak-anak.

\section{KESIMPULAN}

Bahasa reseptif adalah berkaitan dengan kemampuan dalam membedakan suara yang bermakana dan tidak bermakna, bahasa reseptif adalah kemampuan dalam menyimak dan membaca. bahasa reseptif pada Anak, mencakup kemampuan memahami cerita, perintah, aturan, menyenangi dan menghargai bacaan.

Adapun beberapa strategi untuk membantu perkembangan bahasa reseptif adalah: (1) Kegiatan bercerita; (2) Flash Card; (3) Permainan bahasa (simak-ulang ucap, simak-kerjakan, simak-terka, bisik berantai dan bercerita).

Bahasa ekspresif anak adalah kemampuan dalam mengungkapankan bahasa secara verbal dan non verbal. mengekspresikan bahasa, mencakup kemampuan bertanya, menjawab pertanyaan, berkomunikasi secara lisan, menceritakan kembali yang diketahui, belajar bahasa pragmatik, mengekspresikan perasaan, ide, dan keinginan dalam bentuk coretan.

Adapun beberapa strategi untuk membantu perkembanagan bahasa ekspresif anak adalah: (1) Sandiwara Boneka Jari; (2) Bermain Peran; (3) Partners' Dialogic Reading Program

\section{UCAPAN TERIMA KASIH}

Puji syukur kehadirat Allah SWT yang telah memberikan kelancaran dan kemudahan bagi penulis dalam menyelesaikan artikel ini. Terima kasih kepada semua pihak yang telah terlibat dan banyak membantu dalam penyususnan artikel ini, kepada orang tua, teman-teman magister PAUD UNP, dan dosen pengampu mata kuliah.

\section{DAFTAR PUSTAKA}

Alam dan Lestari. (2020). Pengembangan Kemampuan Bahasa Reseptif Anak Usia Dini dalam Memperkenalkan Bahasa Inggris melalui Flash Card. Jurnal Obsesi: Jurnal Pendidikan Anak Usia Dini, 4 (1), 274-279. https://obsesi.or.id/index.php/obsesi/article/view/301/pdf 
Altınkaynak. (2019). Investigation of the Relationship between Parental Attitudes and Children's Receptive and Expressive Language Skills. Universal Journal of Educational Research 7 (3), 892-903. https://eric.ed.gov/?id=ED594211

Bloom, P. (2002). How children learn the meaning of words. Cambridge, MA: MIT Press.

Brannon, et al. 2013. Measuring the Effect That the Partners' Dialogic Reading Program Has on Preschool Children's Expressive Language. Creative Education , 4 (9), 14-17. https://www.researchgate.net/publication/271293008_Measuring the Effect That the Part ners' Dialogic Reading Program Has on Preschool Children's Expressive Language

Brewer, Jo, Ann. (2007). Introduction Early Childhood Education Preschool Trough Primary Grades, Sixth Edition. Boston: Allynan Bacon.

Eliza, D. (2021). Pelaksanaan Perkembangan Bahasa pada Balita di Taman Penitipan Anak Twin Course Pasaman Barat. Jurnal Pendidikan Tambusai, 5(1), 647-650. https://www.jptam.org/index.php/jptam/article/download/1001/898

Hariyanti. (2019). Meningkatkan Kemampuan Bahasa Ekspresif Anak Melalui Metode Bercerita Menggunakan Media Boneka Jari. http://jurnal.upmk.ac.id/index.php/pelitapaud/article/view/520/378

Hart, B., \& Risley, T. (1995). Meaningful differences in the everyday experience of young children. Baltimore, MD: Paul H. Brookes Publishing Company.

Jalongo, M. R. (2007). Early Childhood Language Arts. United States of America.

Khaironi, M. (2018). Perkembangan anak Usia Dini. Jurnnal golden Age Hamzanwadi University, 3(1), 1-12. https://e-journal.hamzanwadi.ac.id/index.php/jga/article/view/739

Khosibah dan Damyati. 2021. Bahasa Reseptif Anak Usia 3-6 Tahun di Indonesia. Jurnal Obsesi: Jurnal Pendidikan Anak Usia Dini, 5 (2), 1860-1869. https://obsesi.or.id/index.php/obsesi/article/view/1015

Kemendikbud. (2014). Peraturan Menteri Pendidikan dan kebudayaan Nomor 137 tahun 2014 tentang Standar Nasional Pendidikan Anak Usia Dini.

Kemendikbud. (2014). Peraturan Menteri Pendidikan dan kebudayaan Nomor 146 tahun 2014 tentang Standar Nasional Pendidikan Anak Usia Dini.

Kurnia, R. (2019). Bahasa anak usia Dini. Yogyakarta: CV Budi Utama.

Laranjo, B \& Bernier. 2013. Children's expressive language in early toddlerhood: links to prior maternal mind-mindedness. Early Child Development and Care, 183 (7), 951-962. https://www.tandfonline.com/doi/abs/10.1080/03004430.2012.699964

Madyawati, L. (2016). Strategi Pengembangan Bahasa Pada Anak. Jakarta: Kencana.

Natalia dan Gandana. (2019). Komunikasi dalam PAUD. Tasikmalaya: Ksatria Siliwangi.

Robingatin \& Ulfah, Z. (2019). Pengembangan Bahasa Anak Usia Dini. Yogyakarta: Ar-ruzz Media.

Santrock, J W. (2007). Perkembangan Anak Jilid 2. Jakarta: Erlangga.

Sari, M. 2020. Penelitian Kepustakaan (Library Research) dalam Penelitian Pendidikan IPA. Jurnal Pnelitian Bidang IPA, 6(1), 41-53. https://ejournal.uinib.ac.id/jurnal/index.php/naturalscience/article/view/1555

Shehadeh, I. I. A., \& Farrah, M. A. A. (2016). The Effectiveness of Using Children 's Songs in Developing Elementary Graders ' English Vocabulary and Pronunciation in Jerusalem , Palestine. Creative Practices in Language Learning and Teaching (CPLT), 4(2). http://dspace.hebron.edu/xmlui/handle/123456789/165

Suardi, dkk. 2019. Pemerolehan Bahasa Pertama Anak Usia Dini. Jurnal Pendidikan Anak Usia Dini, 3(1), 265-273. https://obsesi.or.id/index.php/obsesi/article/view/160

Tika. (2021). Permainan Bahasa Untuk Stimulasi Kemampuan Bahasa Reseptif Anak Usia Dini. Jurnal Penelitian Dan Pemikiran Anak Usia Dini. 7 (1), 1-7. https://ojs.unm.ac.id/tematik/article/download/15355/11020

Viranda, dkk. (2019). Bermain Peran (Role Play) Dan Peningkatan Keterampilan Sosial Anak $\begin{array}{lllllll}\text { Usia Din. Jurnal } & \text { Psikologi, } & 8 & \text { (1), } & 1-6 . & \underline{\text { http://e- }}\end{array}$ journals.unmul.ac.id/index.php/PSIKO/article/view/2255 
Yildiz, et al. (2019). Examining the associations between children's receptive language skills and developmental domains in the United States and Turkey. Journal of Child Language, 1-21. https://pubmed.ncbi.nlm.nih.gov/30700341/

Yunita dan Rohmadheny. (2020). Bermain Peran: Sebuah Metode untuk Meningkatkan Kemampuan Bahasa Ekspresif Anak. Jurnal Obsesi : Jurnal Pendidikan Anak Usia Dini, 5(1), 60-69. https://obsesi.or.id/index.php/obsesi/article/download/509/pdf

Yuhasriati dan Fitriani. (2021). Mengembangkan Bahasa Reseptif Anak Usia Dini Melalui Metode Bercerita Di Raudhatul Athfal Cut Nyak Dhien Gampong Aceh Kabupaten Aceh Timur. Jurnal Ilmiah Mahasiswa Pendidikan Anak Usia Dini, 2(4). http://www.jim.unsyiah.ac.id/paud/article/view/6839

Zed, M. 2004. Metode Penelitian Kepustakaan. Jakarta: Yayasan Obor Indonesia. 